IRA-International Journal of Management \& Social Sciences

ISSN 2455-2267; Vol.08, Issue 01 (July 2017)

Pg. no. 62-73

Institute of Research Advances

http://research-advances.org/index.php/RAJMSS

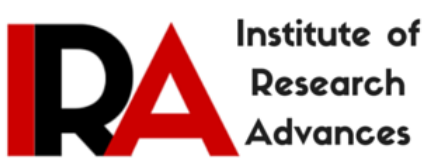

\title{
Effect of Service Quality and Price Perception on Corporate Image, Customer Satisfaction and Customer Loyalty among Mobile Telecommunication Services Provider
}

\author{
Bambang Hermawan ${ }^{1}$, Salim Basalamah ${ }^{2}$, Asdar Djamereng ${ }^{3}$, Annas Plyriadi $^{4}$ \\ ${ }^{1}$ Doctoral Student in the Faculty of Economics, Muslim University of Indonesia, Indonesia. \\ 2,3,4 Faculty of Economics, Muslim University of Indonesia, Indonesia.
}

Type of Review: Peer Reviewed.

DOI: http://dx.doi.org/10.21013/jmss.v8.n1.p7

\section{How to cite this paper:}

Hermawan, B., Basalamah, S., Djamereng, A., \& Plyriadi, A. (2017). Effect of Service Quality and Price Perception on Corporate Image, Customer Satisfaction and Customer Loyalty among Mobile Telecommunication Services Provider. IRA-International Journal of Management \& Social Sciences (ISSN 2455-2267), 8(1), 62-73. doi:http://dx.doi.org/10.21013/jmss.v8.n1.p7

(C) Institute of Research Advances.

\section{(cc) BY-NO}

This work is licensed under a Creative Commons Attribution-Non Commercial 4.0 International License subject to proper citation to the publication source of the work.

Disclaimer: The scholarly papers as reviewed and published by the Institute of Research Advances (IRA) are the views and opinions of their respective authors and are not the views or opinions of the IRA. The IRA disclaims of any harm or loss caused due to the published content to any party.

Institute of Research Advances is an institutional publisher member of Publishers Inter Linking Association Inc. (PILA-CrossRef), USA. The institute is an institutional signatory to the Budapest Open Access Initiative, Hungary advocating the open access of scientific and scholarly knowledge. The Institute is a registered content provider under Open Access Initiative Protocol for Metadata Harvesting (OAI-PMH).

The journal is indexed \& included in WorldCat Discovery Service (USA), CrossRef Metadata Search (USA), WorldCat (USA), OCLC (USA), Open J-Gate (India), EZB (Germany) Scilit (Switzerland), Airiti (China), Bielefeld Academic Search Engine (BASE) of Bielefeld University, Germany, PKP Index of Simon Fraser University, Canada. 


\begin{abstract}
This study aimed to analyze the effect of service quality and price to corporate, customer satisfaction and customer loyalty of mobile telecommunications services in the city of Makassar. Research conducted on customers of mobile telecommunications services by setting a sample of 225 respondents. Data were analyzed using Structural Equation Model (SEM) through Analysis of Moment Structures (AMOS) Ver. 21. The results showed that the quality of the service directly positive and significant effect on corporate image and customer satisfaction. Service quality has a positive and insignificant effect on customer loyalty. Price perception has a positive and significant effect on corporate image, customer satisfaction and customer loyalty. Corporate image has a positive and significant effect on customer satisfaction. Corporate image has a positive and insignificant effect on customer loyalty.
\end{abstract}

Keywords: Service quality, price perception, corporate image, customer satisfaction, loyalty.

\title{
Introduction
}

Mobile telecommunications is a vital tool for the community and has a very important role in the Indonesian economy. The number of subscribers provider of mobile telecommunications in Makassar showed that in general the increase in the number of customers on the overall telecommunications providers mobile from year to year has increased (such as: Provider Tri (3), Indosat and Telkomsel), it means the satisfaction and loyalty of customers continued to increase match what the customer expects.

On the other provider and XL Smartfren experience different conditions, that the quality of service and price given mobile telecommunications provider has been unable to give satisfaction to the customers as per what is expected so that the level of customer satisfaction and loyalty erratic. Changes like this can harm the mobile telecommunications provider, if the customer chooses to switch to other mobile telecommunications providers so that the number of customers decreased. A successful mobile telecommunications provider not only see a one-sided but is done also by analyzing from several sides, such as; high-quality services at affordable prices which is the desire of the customer. But if the quality of services provided less than satisfactory customer and on the other hand an expensive price then customers will switch to other mobile telecommunications providers. In Indonesia the provisions organizing the telecommunications stipulated in government regulations that provide telecommunications services shall provide telecommunications facilities to ensure quality telecommunications services are good (Government Regulation No. 52 of 2000 concerning the organization of Telecommunications Article 15 (1) which is then updated with the Regulation of the Minister of Communications and Information of the Republic of Indonesia Number 7 of 2015 on the second amendment to the Regulation of the Minister of Communication and Information Technology Number 01 / Per / M.Kominfo / 01/2010 on the Implementation of Telecommunication Networks).

Overcoming the problem of customer dissatisfaction, the mobile telecommunications providers are required to improve service quality; good service quality will increase the purchasing decisions of consumers in the company concerned. If consumers are satisfied it is expected that consumers will come back to buy again and even become loyal customers of a company (Griffin, 2005: 110). Service quality has a positive and significant effect on corporate image (Nguyen \& Leblanc, 2002; Toro, 2012). Service quality is positive and significant impact on customer satisfaction (Wendha et al., 2013; Sia \& Subagio, 2013). Discourses' findings, that the quality of services and no significant negative effect on customer satisfaction and customer loyalty (Mahmud et al., 2011; Djaelani, 2011).

Incorrect pricing can be fatal to the company's financial problems and will affect the company's business continuities as continuous losses. Changes in prices has the objective to adjust to the new prices are set to reflect the current cost or the cost of the future costs, the return demanded by the reaction of competitors and so on (Supriyono, 2001: 314). The phenomenon is seen as a result of the competition to capture the market segment of mobile telecommunications services, namely the tendency to price increases, especially in the packet data service. Thus the provider does not realize that the high price increases could be a reference for customers to compare the prices of competitors. If the price is set by the provider is not inconsistent with the expected quality then most likely for customers to switch of 
provider to another competitor. By looking at price competition among providers even though the price difference was small, it may be a consideration for customers.

Empirical evidence suggests that the price effect on customer loyalty (Michael, 2010; Toro, 2012). Inconsistency of the findings shows that the price is not a positive and significant effect on customer loyalty (Basir et al., 2015; Rahyuda \& Atmaja, 2017). In addition to setting the price according to the quality provided by the provider to the customer, the provider should always provide good quality services to consumers through imagery provider. Corporate image is the result of a collection of processes in which consumers compare the various attributes of the company (Nguyen \& Leblanc, 2005).

Empirical evidence shows that on several occasions provider overlook customers when customers make suggestions, complaints and so on, the company was not aware that the service was not optimal in the sense not to give satisfaction to the customer then the image of the company will have decrease in both the name of both the company and the concerned with the company. Build a good reputation is important for companies to have the hearts of customers. The findings of previous researchers provide evidence that the company's image significantly influence customer satisfaction (Hu \& Huang, 2011; Huang, 2016; Rahyuda \& Atmaja, 2017).

Customer satisfaction has become part of the goal of most companies. The quality of service for service companies becomes very important in order to give more satisfaction to the customers and ultimately add value to the company itself. The findings of previous researchers, proving that influence satisfaction to customer loyalty (Michael, 2010; Mahmud et al., 2011; Wendha et al., 2013; Chotivanich, 2014). Inconsistency findings provide new evidence that satisfaction and no significant negative effect on customer loyalty (Romeo 2008).

\section{Literature review}

\section{Service quality}

Quality is one factor used by consumers to buy a product in the form of goods or services, in which a product can be compared with its competitors based on its quality. The values given customer, very strong based on the factors of service quality. Where the quality of a product or service is the extent to which products or services meet the specifications. The success of an action is determined by the quality of the services. Quality is the highest appreciation of the acts of service. The quality of a match, which means the use of goods or services in order to meet customer needs (Roger, 1995).

One model of service quality that made reference in marketing research is a model ServQual (Parasuraman et al.,1988) in a series of their study of the six service sectors, repair, home appliances, credit cards, insurance, longdistance calls, automotive, retail, and securities brokers. ServQual built on their comparison of two main factors, namely the perception of the real customers for the services they perceived service with actual services expected service. Past studies provide evidence that the services quality is positive and significant effect on corporate image (Toro, 2012; Nguyen \& Leblanc, 2005; Jasfar, 2005).

ServQual is positive and significant effect on customer satisfaction (Tjitono \& Diana, 2001; Wendha et al., 2013; Sia \& Subagio, 2013). The findings were obtained rebuttal that the services quality is negative and insignificant effect on customer satisfaction and customer loyalty (Mahmud et al., 2011; Djaelani, 2011). Service quality measurement in this study using the dimensions of SERVQUAL (Parasuraman et al., 1988), include; (1) tangible, (2) reliability (3) responsiveness, (4) assurance, and (5) empathy.

\section{Price perception}

Price has a very important role in influencing consumer decisions to buy products, so as to determine the success of marketing a product. Price is the amount of money charged for a product or service, or the amount of value exchanged for consumers on the benefits for owning or using a product or service (Kotler \& Armstrong, 2001: 439). Consumers in looking at a certain price, high, low, fair, have a strong influence on purchase intent and satisfaction. It shows that a consumer assess the reasonableness of a price for goods and services is highly dependent on how vote (Schiffman \& Kanuk, 2010).

Pricing is wrong can be fatal to the financial problems, artefacts four orientations used in price fixing, namely: (1) oriented income, (2) Oriented Volume, (3) oriented image, and (4) oriented stabilization (Tjiptono, 2008: 152). 
Empirical evidence suggests that the price effect on customer loyalty (Michael, 2010; Toro, 2012). Inconsistency of the findings shows that the price is not a positive and significant effect on customer loyalty (Rahyuda \& Atmaja, 2017; Basir et al., 2015). Measurements price perceptions on this study to develop constructs price (Supriyono, 2001: 314; Tjiptono, 2008: 152), which includes; (1) affordable price, (2) rates effective, (3) prices are competitive with other operators, (4) attractive bonus, and (5) compliance with the price of the network quality.

\section{Corporate image}

The image is the public perception of the company or its services produced by the company. Another view mentioned image as impression thought and known to a person or group on a matter both the company and its products acquired through experience (Alma, 2000: 317). Corporate image is the result of a collection of processes in which consumers compare the various attributes of the company. Attributes are meant for example a product, price, product quality and service quality. Consumer's image is where the company will make a subjective perception of the company and all its activities.

That perception will be different for everyone even if faced with the same object (Nguyen \& Leblanc, 2005). The findings of previous researchers provide evidence that the corporate image significantly effect on customer satisfaction (Rahyuda \& Atmaja, 2017; Hu \& Huang, 2011; Huang, 2016). The construct of corporate image measurement in this study developed a perceptual construct the price (Nguyen \& Leblanc, 2005; Jasfar, 2005: 55), which includes; (1) excellent customer impression, (2) the actions of companies who are honest, (3) the image / good image in society, (4) The hospitality in serving customers, (5) Having the advantages of the product compared with competitors.

\section{Customer Satisfaction}

Customer satisfaction is the consumer response to the evaluation of the perception of the difference between the initial expectations or certain performance standards and actual performance as perceived product after product consumption. The purpose of this definition is that if the performance of the product, whether goods or services, much lower than the expectations of customers, buyers can be said to be dissatisfied.

Conversely, if the performance in line with expectations or even exceed expectations, then the buyer will feel satisfied or very happy (Tse \& Wilton, 1988). The findings of previous researchers, Customer satisfaction is significant on customer loyalty (Michael, 2010; Mahmud et al., 2011; Wendha et al., 2013; Chotivanich, 2014). Inconsistency findings provide new evidence that satisfaction and no significant negative effect on customer loyalty (Romeo 2008). Measurement of customer satisfaction is important for the company, because by knowing the level of customer satisfaction, the company obtain feedback and inputs for the purposes of developing and implementing the strategy further increase customer satisfaction. Expectation-Disconfirmation Theory is a theory that underlies the customer satisfaction. Satisfaction is a discrepancy fulfilling the needs and desires continued gap between the expectations of the desired destination (Ramli \& Sjahruddin, 2015). The construct of customer satisfaction using measurement Kotler (1997), include; (1) Products that provide benefits, (2) Communication with customers, (3) services provided in accordance with what is desired, (4) Costs incurred in accordance with customer expectations, and (5) Ease of transacting.

\section{Customer loyalty}

Customer loyalty as a customer commitment to a brand, the store, the supplier is based on a very positive attitude and is reflected in the consistent purchase (Tjiptono, 2000: 110). Customer loyalty is customer commitment to survive in depth to re-subscribe or re-purchase of goods / services selected consistently in the future, although the influence of the situation and marketing efforts have the potential to cause a change in the desired behaviour (Ramli \& Sjahruddin, 2015). Another view explains that customer loyalty is customer attachment to a brand, stores, manufacturers, service providers or other entities based on a favourable attitude and a good response as repurchase (Widjaja, 2008: 6).

Past studies provide evidence that the quality of positive and significant effect on loyalty through customer satisfaction (Chotivanich, 2014). Service quality and price has a positive and insignificant effect on loyalty through customer satisfaction (Basir et al., 2015). Constructs measurement of customer loyalty develop measurement (Griffin, 2005: 31; Widjaja, 2008), include; (1) repurchase, (2) indifference to a negative influence on the product, (3) Recommend to others (customer confidence when using the product, and (5) Not easily affected by persuasion or sale of competitors. 


\section{Methods}

The study population are customer of mobile telecommunications services (Telkomsel, Indosat, XL, Tri and Smartfren) in Makassar city. Accidental sampling technique is used to obtain a sample of 225 customers. Data were analyzed using Structural Equation Model (SEM) through Analysis of Moment Structures (AMOS) Ver. 21 program that tests relationships between observed and latent (unobserved) variables to quickly intervening test hypotheses and confirm relationships

\section{Results}

\section{Characteristics of respondents}

A characteristic of respondents in this study is used to elaborate or give an idea about the identity of respondents, including Gender, Age (years), level of education and profession. For it can be shown in the following table:

Table 1. Characteristics of respondents

\begin{tabular}{|c|c|c|c|}
\hline \multicolumn{2}{|c|}{ Characteristics of respondents } & \multirow{3}{*}{$\begin{array}{c}\text { Frequency }(\mathrm{n}=225) \\
109 \\
116 \\
\end{array}$} & \multirow{3}{*}{$\begin{array}{c}\text { Percent }(\%) \\
48,44 \\
51,56 \\
\end{array}$} \\
\hline Gender & Male & & \\
\hline Geriate & Female & & \\
\hline \multirow{5}{*}{ Age (years) } & $10-20$ & 48 & 21,33 \\
\hline & $21-30$ & 126 & 56,00 \\
\hline & $31-40$ & 31 & 13,78 \\
\hline & $41-50$ & 11 & 4,89 \\
\hline & $\geq 51$ & 9 & 4,00 \\
\hline \multirow{6}{*}{ Education } & Primary school & 2 & 0,89 \\
\hline & Junior high school & 18 & 8,00 \\
\hline & Senior high school & 101 & 44,89 \\
\hline & Diploma & 8 & 3,56 \\
\hline & Bachelor degree & 71 & 31,56 \\
\hline & Master degree & 25 & 11,11 \\
\hline \multirow{6}{*}{ Profession } & Student & 109 & 48,44 \\
\hline & civil servants & 18 & 8,00 \\
\hline & Private employees & 62 & 27,56 \\
\hline & entrepreneur & 20 & 8,89 \\
\hline & Housewife & 6 & 2,67 \\
\hline & the others & 10 & 4,44 \\
\hline
\end{tabular}

The table explains that respondents by gender is characterized predominantly by women, as many as 116 respondents (51.56\%), then for age, demonstrated at the age of 21-30 years, as many as 126 respondents (56.00\%), further to the level of education, demonstrated by the Senior final high school education as many as 101 respondents $(44.89 \%)$, and the latter is based on the work indicated by respondents who work as a student, as many as 109 respondents $(48.44 \%)$.

\section{Discussion}

The results test between variables effect, either directly or indirectly (hypothesis) is can be described as follows: 
Table 2. Hypothesis testing

\begin{tabular}{|c|c|c|c|c|c|c|c|}
\hline \multirow[b]{2}{*}{$\begin{array}{l}\text { Exogenous } \\
\text { variable }\end{array}$} & \multirow[b]{2}{*}{$\begin{array}{l}\text { Intervening } \\
\text { variable }\end{array}$} & \multirow[b]{2}{*}{$\begin{array}{l}\text { Endogenous } \\
\text { variable }\end{array}$} & \multicolumn{5}{|c|}{ Standardized } \\
\hline & & & $\begin{array}{l}\text { Direct } \\
\text { effects }\end{array}$ & $\begin{array}{l}\text { Indirect } \\
\text { effects }\end{array}$ & $\begin{array}{r}\text { Total } \\
\text { effects }\end{array}$ & $\begin{array}{c}\text { p-value } \\
\text { (typically } \\
<0,05 \text { ) }\end{array}$ & $\begin{array}{l}\text { Hypothesis } \\
\text { testing }\end{array}$ \\
\hline SERVQUAL & - & $\begin{array}{l}\text { Corporate } \\
\text { Image }\end{array}$ & 0,690 & - & 0,690 & 0,000 & accepted \\
\hline SERVQUAL & - & $\begin{array}{c}\text { Customer } \\
\text { satisfaction }\end{array}$ & 0,306 & - & 0,306 & 0,003 & accepted \\
\hline SERVQUAL & - & $\begin{array}{l}\text { Customer } \\
\text { Loyalty }\end{array}$ & 0,179 & - & 0,179 & 0,162 & rejected \\
\hline $\begin{array}{c}\text { Price } \\
\text { perception }\end{array}$ & - & $\begin{array}{l}\text { Corporate } \\
\text { Image }\end{array}$ & 0,254 & - & 0,254 & 0,000 & accepted \\
\hline $\begin{array}{c}\text { Price } \\
\text { perception }\end{array}$ & - & $\begin{array}{l}\text { Customer } \\
\text { satisfaction }\end{array}$ & 0,223 & - & 0,223 & 0,000 & accepted \\
\hline $\begin{array}{c}\text { Price } \\
\text { perception }\end{array}$ & - & $\begin{array}{c}\text { Customer } \\
\text { Loyalty }\end{array}$ & 0,207 & - & 0,207 & 0,014 & accepted \\
\hline $\begin{array}{l}\text { Corporate } \\
\text { Image }\end{array}$ & - & $\begin{array}{l}\text { Customer } \\
\text { satisfaction }\end{array}$ & 0,434 & - & 0,434 & 0,000 & accepted \\
\hline $\begin{array}{l}\text { Corporate } \\
\text { Image }\end{array}$ & - & $\begin{array}{c}\text { Customer } \\
\text { Loyalty }\end{array}$ & 0,102 & - & 0,102 & 0,526 & rejected \\
\hline $\begin{array}{c}\text { Customer } \\
\text { satisfaction }\end{array}$ & - & $\begin{array}{c}\text { Customer } \\
\text { Loyalty }\end{array}$ & 0,375 & - & 0,375 & 0,006 & accepted \\
\hline SERVQUAL & - & $\begin{array}{c}\text { Customer } \\
\text { Loyalty }\end{array}$ & 0,179 & - & 0,249 & 0,528 & rejected \\
\hline SERVQUAL & $\begin{array}{l}\text { Customer } \\
\text { satisfaction }\end{array}$ & $\begin{array}{c}\text { Customer } \\
\text { Loyalty }\end{array}$ & 0,179 & 0,115 & 0,294 & 0,044 & accepted \\
\hline $\begin{array}{c}\text { Price } \\
\text { perception }\end{array}$ & $\begin{array}{c}\text { Corporate } \\
\text { Image }\end{array}$ & $\begin{array}{c}\text { Customer } \\
\text { Loyalty }\end{array}$ & 0,207 & 0,026 & 0,233 & 0,532 & rejected \\
\hline $\begin{array}{c}\text { Price } \\
\text { perception }\end{array}$ & $\begin{array}{c}\text { Customer } \\
\text { satisfaction }\end{array}$ & $\begin{array}{c}\text { Customer } \\
\text { Loyalty }\end{array}$ & 0,207 & 0,084 & 0,291 & 0,030 & accepted \\
\hline SERVQUAL & $\begin{array}{c}\text { Corporate } \\
\text { Image and } \\
\text { Customer } \\
\text { satisfaction }\end{array}$ & $\begin{array}{l}\text { Customer } \\
\text { Loyalty }\end{array}$ & 0,179 & 0,227 & 0.406 & 0,000 & accepted \\
\hline $\begin{array}{c}\text { Price } \\
\text { perception }\end{array}$ & $\begin{array}{l}\text { Corporate } \\
\text { Image and } \\
\text { Customer } \\
\text { satisfaction }\end{array}$ & $\begin{array}{l}\text { Customer } \\
\text { Loyalty }\end{array}$ & 0,207 & 0,124 & 0,331 & 0,000 & accepted \\
\hline
\end{tabular}

\section{Linking of the Servqual on corporate Image}

The hypothesis testing $\left(\mathrm{H}_{1}\right)$ proved to be accepted, that the services quality is positive and significant impact on the image of the company is accepted. This is evidenced by the value of a standardized beta coefficient of 0,690 and $p$ value $0,000<0,05$. This shows that the indicators that make up the services quality can be giving out a good contribution to the image of the company, the higher the quality of service the company's image will be higher, because all indicators of service quality variables such as physical evidence, reliability, responsiveness, assurance and a sense of care for the company urgently needed by companies (providers) to achieve a good image in the eyes of the public or customers.

Significant influence is happening is the result of the overall contribution of the variables / indicators of the quality of service that affect the realization of a good corporate image, or in other words a good services quality will determine a good corporate image in the minds of the customer anyway. Employees are able to provide fast service, willingness to help the customer, ready to handle criticism / customer complaints, the response of employees on customer suggestions and be able to educate / provide guidance to customers regarding the surrounding 
telecommunications so that the quality provided to the customer is able to foster a sense of satisfaction with using the services of the company.

This study relevant on the holy Quran (Surah Al-Imran, 115), that every human being is required to do good to their fellow human beings, including the improvement of services in order to create a good corporate image (positive) in the eyes of the public / customers. This study supports the statement that services quality experts can affect the image of a company because the company's image is the result of a collection of processes in which consumers compare the various attributes of the company (Nguyen \& Leblanc, 2005). Supports the findings of previous investigators, that the quality of their services and significant positive effect on the image of the company (Toro, 2012).

\section{Linking of Servqual on customer satisfaction}

The hypothesis testing $\left(\mathrm{H}_{2}\right)$ proved to be accepted, that the services quality is positive and significant impact on customer satisfaction. This is evidenced by the value of a standardized beta coefficient of 0,306 and $p$-value $0,003<$ 0,05 , that the higher of services quality that will increase customer satisfaction. Services quality is implemented by the company is able to give a good first impression and services in accordance with the promotion is not just a promise, so that what is earned by the customer in accordance with will be desired, the company also must take responsibility for problems of service experienced by customers, other than that the employee must provide timely service and also provide information about when the service would do promised.

This study relevant on the holy Quran (Surah Al Hajj, 77), that every human being is required to do good to their fellow human beings, including in terms of improved service to foster a sense of satisfaction to the customer. This study supports the theory that Servqual dimension, tangible reliability, responsiveness, assurance and empathy the dimensions of service quality are applied to achieve customer satisfaction (Parasuraman et al., 1988). Then it will be an important consideration for customers to be able to fulfil their needs so that it will create customer satisfaction (Parasuraman et al., 1988). Service quality is positive and significant impact on customer satisfaction (Tjitono \& Diana, 2001; Wendha et al., 2013; Sia \& Subagio, 2013).

\section{Linking of Servqual on customer loyalty}

The hypothesis testing $\left(\mathrm{H}_{3}\right)$ is rejected, that the service quality is positive and significant impact on customer loyalty. This is evidenced by a standardized beta coefficient value of 0,179 and a p-value of $0,162>0,05$, this condition means that the higher the service quality, but the effect is not significant for the high customer loyalty, the tangible (physical evidence) dimensions of which felt directly by the customer on the quality of the services provided by the company. as in fact has been providing comfortable waiting room so clients can wait queue properly, the availability of the equipment in accordance with the wishes of the customer to meet its needs, officials are trying to provide services in accordance with the wishes of customers, providing appropriate equipment and employees strive to always dressed interesting to introduce identity as executor service.

This finding contrasts with the statements of experts, that the service quality is the delivery of services that will exceed the level of consumer interest, that the provision of services or higher quality services are that meet and even exceed the needs and expectations of customers (Rangkuti, 2003: 28). Results of studies reject previous studies, that the service quality positive and significant effect on customer loyalty (Toro, 2012).

\section{Linking of price perception on corporate image}

The hypothesis testing $\left(\mathrm{H}_{4}\right)$ proved to be accepted, that the price perception is positive and significant impact on the corporate image. This is evidenced by the value of a standardized beta coefficient of 0,223 and p-value of $0,000<$ 0.05 , that price is more competitive provides improved the corporate image. Appropriate pricing may affect the realization of a better corporate image, or in other words, determine the price of a company's image provided by the mobile telecommunications service company in the city of Makassar. Pricing is right in line with what is expected by the customer.

This study relevant on the holy Quran (Surah Al-Imran, 115), that every human being is required to do good to their fellow human beings, including in terms of pricing in order to create a good corporate image (positive) in the eyes of the public / customers. Supports the concept of corporate image can be formed through pricing strategies. Companies can set a high price to establish or maintain a prestigious image. Meanwhile, the low price may be used 
to form the image of a certain value (image of value), for example by ensuring that the price is the lowest price in a given region (Tjiptono, 2008: 153).

\section{Linking of price perception on customer satisfaction}

The hypothesis testing $\left(\mathrm{H}_{5}\right)$ proved to be accepted, that the price perception is positive and significant impact on customer satisfaction. This is evidenced by the beta value to a standardized coefficient of 0,223 and $p$-value of 0.000 $<0.05$, that price is more competitive, it is increasingly provides enhanced customer satisfaction pricing can affect the realization of customer satisfaction or in other words the price determines the level of satisfaction top customer service provided by the mobile telecommunications service company in the city of Makassar.

This study relevant on the holy Quran (Surah Saba, 4), that all men are required to do good to their fellow human beings, including in terms of reasonable pricing in order to create customer satisfaction with the good. This study supports the statement of the expert, that price is an amount of money charged for a particular product. Pricing appropriate to the service and performance offered by the company can create customer satisfaction; customer satisfaction can create customer loyalty (Sunyoto, 2012: 131). The quality of price fixing price determined in accordance with the products offered (O'Malley, 1998). The offer price will determine the price of demand (Friedman, 2008). Price is significant effect on customer satisfaction (Sia \& Subagio, 2013; Toro, 2012).

\section{Linking of price perception on customer loyalty}

The hypothesis testing $\left(\mathrm{H}_{6}\right)$ proved to be accepted, that the price perception is positive and significant impact on customer loyalty. This is evidenced by the value of a standardized beta coefficient of 0,207 and $p$-value of $0,014<0$, 05 . That price is more competitive then increasingly provides an increase in customer loyalty. The Company provides pricing policies decent form / according to the customer to have the customer loyalty that can benefit the company. Pricing is affordable, saving rates, the amount of the bonus, suitability prices with quality service and its competitive price with other operators is one factor that may affect the realization of customer satisfaction levels.

This study relevant on the holy Quran (Surah $\mathrm{Al}$ - Imran, 115), that every human being is required to do good to their fellow human beings, including in terms of pricing in order to create a good customer loyalty (positive) in the eyes of the public / customers. This study supports the statement of the expert, that price is an amount of money charged for a particular product. Pricing appropriate to the service and performance offered by the company can create customer satisfaction, customer satisfaction can create customer loyalty (Sunyoto, 2012: 131) the quality of the price is determined on the pricing appropriate to the products offered (O'Malley, 1998). The offer price will determine the price of demand (Friedman, 2008). Prices are positive and significant impact on customer loyalty (Michael, 2010).

\section{Linking corporate image on customer satisfaction}

The hypothesis testing $\left(\mathrm{H}_{7}\right)$ proven to be accepted, that the image of the company and significant positive effect on customer satisfaction. This is evidenced by the value of a standardized beta coefficient of 0,434 and $p$-value of 0,000 $<0,05$ that the higher corporate image is increasing on customer satisfaction. Companies improve services so that the impression perceived by the customer against the company for the better, the company has an honest action, the company has a good image in the eyes of the people, the friendliness of the employees in serving customers and have the advantages of the products compared with competitors. Providing special assessment that the presence of a good corporate image applied by the company is in accordance with what is expected by the customer so as to realize customer satisfaction.

This study relevant on the holy Quran (Surah Al Isra, 35), that the measure when ye measure, and weigh with a balance that is true, it indicates that by giving the right dosage based on what was supposed to show that a good corporate image if giving something in accordance with what it should be in order to make sense of trust and customer satisfaction. Supports on statement of the expert that the corporate image is a mixture of functional and emotional aspects that previous experiences between consumers and companies such as advertisements, word of mouth, hope will come the direct positive effect on customer satisfaction. If consumers ever get a good experience with a company, then the satisfaction will increase. Conversely when ever happen bad experience, then satisfaction would decline (Berman \& Evans, 1995). Corporate image is a positive and significant effect on customer satisfaction (Sia \& Subagio, 2013; Huang, 2016). 


\section{Linking of corporate image on customer loyalty}

The hypothesis testing $\left(\mathrm{H}_{8}\right)$ is rejected, that the corporate image is positive and insignificant effect on customer loyalty. It was proven value to a standardized beta coefficient of 0,102 and $p$-value of $0,526>0,05$, that the higher the company's image, the more increase customer loyalty but the increase was not real. This study relevant on the holy Quran (Surah Ibrahim, 51), that the God will require each person for what he earned, this indicates that by providing a good service that can provide value / positive image for the company is to be expected for any service provider to create things positive in the eyes of the public / customers. Good corporate image will foster loyalty / customer loyalty to continue using the service / services of the company. The results of this study rejected the findings of previous investigators, that the image of the company and significant positive effect on customer loyalty (Toro, 2012).

\section{Linking of customer satisfaction on customer loyalty}

The hypothesis testing $\left(\mathrm{H}_{9}\right)$ proved acceptable, customer satisfaction and significant positive effect on customer loyalty. It was proven value to a standardized beta coefficient of 0,375 and p-value of $0,006<0,05$, that an increase in customer satisfaction has a significant impact on improving customer loyalty. Customers whose needs are met automatically be satisfied that impact on customer loyalty. When customers perform service activities on the part of companies feel fulfilled his wish that customers will be satisfied with the fulfilment of the service to use the facilities / equipment as required by the customer. These findings are relevant to the concept of activity satisfaction of services provided by the company to the customer is crucial vote to express feelings of pleasure or disappointment services received. Satisfaction of services directly impact on customer loyalty. Customer satisfaction in accordance with the wishes will always be consistent and have a high commitment to show loyalty (Parasuraman et al., 1988).

This study relevant on the holy Quran (Surah Annisa, 58), that every human being is required to convey trust and establish rules among fellow human beings with equal justice to those who deserve it, including in terms of providing satisfaction to foster loyalty / customer loyalty. Customer satisfaction is positive and significant effect on customer loyalty (Michael, 2010; Sia \& Subagio, 2013; Toro, 2012; Ramli \& Sjahruddin, 2015; Huang, 2016).

\section{Linking of service quality on customer loyalty: The mediating role of corporate image}

The hypothesis testing $\left(\mathrm{H}_{10}\right)$ is rejected, that the quality of service is positive and significant impact on customer loyalty through the company's image. It was proven value to a standardized beta coefficient of 0,070 and p-value of $0,528>0,05$. Employees of the company provide fast service, willingness to help the customer, ready to handle criticism / customer complaint, a response officer on the advice of customers and be able to provide guidance to customers regarding telecommunications around so that the quality provided to customers have not been able to foster customer loyalty through the company's image.

This finding contrasts with the statements of experts, that customer loyalty is customer attachment to a brand, parking, service providers / service, or other entity based on a favourable attitude and a good response as repurchase (Widjaja, 2008: 6). Assessing customers loyal or disloyal views of fidelity repurchase regularly, always recommend the experience to others reference on services received and show a positive response for services offered (Griffin, 2005). the services quality is positive and insignificant effect on customer loyalty through the company's image is due to the quality of service received by customers of the companies has not reflect a good image in the eyes of society so that the level of customer loyalty is uncertain or can move to other competitors.

\section{Linking of service quality on customer loyalty: The mediating role of customer satisfaction}

The hypothesis testing $\left(\mathrm{H}_{11}\right)$ proved to be accepted, that the quality of service is positive and significant impact on customer loyalty. It was proven value to a standardized beta coefficient of 0,115 and $p$-value of $0,044<0,05$. This result occurs because of all the indicators of service quality from all dimensions such as the dimensions of the physical evidence, reliability, responsiveness, assurance and sense of care still needs to be improved or corrected to affect an increase in customer loyalty through customer satisfaction.

Customer loyalty is reflected in the ratings on the products and services that have the feasibility or appropriateness (Holmes, 2009: 66). Services quality is positive and insignificant effect on customer loyalty through customer satisfaction (Djaelani, 2011; Sia \& Subagio, 2013; Huang, 2016). 


\section{Linking of price perceptions on customer loyalty: The mediating role of corporate image}

The hypothesis testing $\left(\mathrm{H}_{12}\right)$ is rejected, that price positive and significant impact on customer loyalty through the company's image. It was proven value to a standardized beta coefficient of 0,026 and p-value of 0,532>0, 05 . Affordable pricing and saving rates would be a guarantee to fix prices on the Vendor to enhance customer loyalty to constantly repeat purchase activity, to tell the positive thing about the prices received, and recommend to other customers. Indirectly pricing based on the level of saving rates and affordable prices have not been able to influence customer loyalty through the company's image. The findings of this study differs from previous studies that the price is positive and significant impact on customer loyalty through corporate image (Toro, 2012).

\section{Linking of price perception on customer loyalty: The mediating role of customer satisfaction}

The hypothesis testing $\left(\mathrm{H}_{13}\right)$ proved to be accepted, that the price perception is positive and significant impact on customer loyalty through customer satisfaction. This is evidenced standardized beta coefficient value of 0,084 and a p-value of $0,030<0,05$. Customers are always loyal to the pricing of the service efficient, affordable and conformity with the price of the network quality. So customers always loyal to perform repetitive service activities, recommend to other customers, communicating a positive thing for the service obtained and encourage other customers to receive the same service. This study supports the findings of previous investigators, that the price of a significant and positive impact on customer loyalty through customer satisfaction (Michael, 2010; Sia \& Subagio, 2013; Huang, 2016).

\section{Linking of servqual on customer loyalty: The mediating role of corporate image and customer satisfaction}

The hypothesis testing $\left(\mathrm{H}_{14}\right)$ proved to be accepted, that the quality of service is positive and significant impact on customer loyalty through corporate image and customer satisfaction. This is evidenced standardized beta coefficient value of 0,227 and a p-value of $0,000<0,05$. Tangible (physical evidence), it is felt directly by the customer on the quality of services provided by the company. as in fact has been providing comfortable waiting room so clients can wait queue properly, the availability of equipment according to customer wishes to meet its needs, employees strive to provide services in accordance with the wishes of customers, providing appropriate equipment and employees strive to always look attractive to introduce identity as service delivery. In addition, the enterprises should also be giving out the appearance of the interior / exterior of interest so that customers can enjoy what is around the company and not least the company provides sufficient parking for customers of mobile telecommunications services.

The concept of customers is very sensitive customers with products that are memorable, evocative and foster loyalty. Sensitivity assures customer loyalty. This gives an indication that the sensitivity is closely related to customer loyalty (Carr, 2012: 39).

\section{Linking of price perception on customer loyalty: The mediating role of corporate image and customer} satisfaction

The hypothesis testing $\left(\mathrm{H}_{15}\right)$ proved to be accepted, that the price perception is positive and significant impact on customer loyalty through corporate image and customer satisfaction. It was proven value to a standardized beta coefficient of 0,124 and $p$-value of $0,000<0,05$. Affordable pricing and saving rates would be a guarantee to fix prices on the Vendor to enhance customer loyalty to constantly repeat purchase activity, tell positive things about the prices received, and recommend to other customers. Indirectly pricing based on the level of saving rates and affordable prices will have an impact on customer satisfaction, so that customers who feel unfulfilled desire will always be loyal to the mobile telecommunications services. Supports the concept of the balance of the price that the bid price will determine the price of demand (Friedman, 2008). The quality of price fixing price determined in accordance with the products offered (O'Malley, 1998)

\section{Conclusions and recommendations}

Service quality given by the employee of mobile telecommunication services provider always responding good service, serve in accordance with the physical evidence of service that is owned, has the ability to understand the services that customers want a reliable, on services needed by the customer and guarantee the right services time in serving customers in order to meet the customers' needs. Implementation of the service quality dimensions applied to develop the empowerment of service, using technology with good service, a good failure recovery in a variety of service activities, so that customers feel unfulfilled needs and desires so that the impact on satisfaction with the services provided by the mobile telecommunications services company. 
Service quality is implemented by the company has not been optimal, the use of technology that is still less appropriate services, so that customers need not feel fulfilled in accordance what he wanted. Pricing policy applied by the company's mobile telecommunications services competitive and interesting bonus, at affordable prices to meet the needs of customers who have an impact on the image of company. Pricing policy, mobile telecommunications services company, is able to provide competitive price (cheap / affordable), the more interesting bonus, saving rates and better network quality. Price perception has a positive and significant impact on customer satisfaction based pricing policies, optimal telecommunications company can provide a cheaper price / affordable, their bonuses more than the provider, saving rates and better network quality.

The level of satisfaction felt by customers on unmet needs in accordance with what is desired, customers communications in cultivating customer loyalty intensive mobile telecommunications services, recommend to other customers, communicating a positive thing for services received and satisfactory service priority. The provision of quality service has not been applied properly to meet customer loyalty, resulting in improved services that impact on the improvement of the corporate image is an important consideration to be addressed in increasing loyalty through the company's image.

The provision of service quality implemented by the company is able to meet the level of customer satisfaction that have an impact on customer loyalty. Pricing is expensive or difficult to reach by the customer and less attractive bonus is that customers will have a negative impact on the image of a company so that the level of customer loyalty will decline. By paying attention to the proper pricing policy by giving bonuses attractive, affordable and frugal fare, became one of the company's policies that favour the customer, thus increasing the level of customer loyalty by fulfilling customer satisfaction.

The provision of the high services quality that have been implemented by the company to achieve the level of customer loyalty, the improved service quality is very influential in customer loyalty either through a corporate image and customer satisfaction, improved service quality, corporate image and customer satisfaction is very noticed by customers and will have an impact on customer loyalty due to good quality care will positively affect the company's image and the image of a good standard enterprise will affect the customer satisfaction and customer satisfaction will automatically affect the level of customer loyalty.

Competitive pricing and incentive attractive to customers will have a positive impact on the company's image and good image will affect the level of customer satisfaction and will automatically positive impact on customer loyalty. Increased satisfaction based quality of service to enhance customer loyalty by finding tricks innovation and quality services, satisfying and make a commitment to keep loyal customers using mobile telecommunications services.

Companies are required to make a breakthrough in the quality of service in favour of the interests of customers by providing a range of services that is easy, fast and on time according to the purpose of the service, so customers have a high loyalty as fulfilled satisfaction. It is expected to the company to provide better bonus and attractive discounts and special rates to customers who frequently use the services that are repetitive and recommend to other customers and invite people to prioritize the selection of services being offered, so the appropriateness customers get discounts mutually prosper between the providers to the customer. Creating the image of cellular telecommunications Services Company well to the company's customers in the eyes of customers who use the service can be more confident that can create customer satisfaction.

\section{References}

1. Alma, Buchari. (2004). Strategic Marketing Services Marketing. Bandung: CV publisher. Alfabeta

2. Basir, M., Modding, B., Kamase, J., \& Hasan, S. (2015). Effect of Service Quality, Orientation Services, and Pricing on Loyalty and Customer Satisfaction on Marine Transportation Services. International Journal of Humanities and Social Science Invention, 1-6.

3. Berman, B \& Evans, R. (1995). Retailing Management. $6^{\text {th }}$ edition, New Jersey : Prentice Hall

4. Carr , L.P. (2012). Front-Line Customer Service Orientation. New York: John Wiley \& Sons, Inc. New York.

5. Chotivanich, P. (2014). Service Quality, Satifaction, and Customer Loyalty in a Full-Service Domestic Airline in Thailand. International Journal of Arts \& Sciences, 7(3), 161.

6. Djaelani, Abdul Qadir. (2011). Effect of Service Quality, Price and Service Orientation to Customer Satisfaction and Loyalty Card Halo Telkomsel. PPS Brawijaya university Dissertation. Malang

7. Friedman, Sturt. (2008). Application of Quality Service Theory. Published by John Wiley abd Sons, Usa. 
8. Griffin, J. (2005). Customer Loyalty: Growing and maintaining customer loyalty. Revised and latest edition. Jakarta: Erlangga Publisher

9. Holmes, Marthin. (2009). Marketing Mix: Product, Price, Distribution and Promotion. Prentice Hall Jersey University Press, America.

10. Hu, K. C., \& Huang, M. C. (2011). Effects of service quality, innovation and corporate image on customer's satisfaction and loyalty of air cargo terminal. International Journal of Operations Research, 8(4), 36-47.

11. Huang Ching Lin. (2016). Relationship Among Corporate Image, Service Qualty, Switching Cost, Customer Satisfaction and Loyalty: An Example of Toyota's Distribution in Taiwan. International Journal of Information Technology and Business Management. Vol.5(1).

12. Jasfar, Farida. (2005). Management Services. Integrated approach. Bogor: Ghalia Indonesia

13. Kotler, Philip \& Armstrong, Gary. (2008). The basics of marketing. Ninth Edition. Prenhalindo. Jakarta

14. Kotler, Philip. (1997). Marketing For Health, Care Organization. New Jersey: Prentice Hall, Inc

15. Mahmud, Amir, Kamaruzaman ans \& St Hadijah, (2011). The Effect of Service Quality and Price on Satisfaction and Loyalty of Customer of Commercial Flight Service Industry World Applied Sciences Journal 23 (3): 354-359.

16. Michael, Dean. (2010). Improvoment Customer Satisfaction, Service Quality, Price and Service Orientation toward Increasing the Loyalty and Marketing Performnce of General Hospital in New York. Marketing Management Journal, Vol. 17, p. 13-16

17. Nguyen, N., \& Leblanc, G. (2002). Contact personnel, physical environment and the perceived corporate image of intangible services by new clients. International Journal of Service Industry Management, 13(3), 242-262.

18. O’Malley, L. (1998). Can loyalty schemes really build loyalty?. Marketing Intelligence \& Planning, 16(1), 47-55.

19. Parasuraman, A., Zeithaml, V. A., \& Berry, L. L. (1988). Servqual: A multiple-item scale for measuring consumer perc. Journal of retailing, 64(1), 12.

20. Rahyuda, I. K., \& Atmaja, N. P. C. D. (2017). The influence of price fairness, corporate image to the satisfaction and loyalty of Gia domestic flight users in Denpasar. EQUITY (Journal of Economics and Finance), 15 (3), 370 395.

21. Ramli, A. H., \& Sjahruddin, H. (2015). Building patient loyalty in healthcare services. International Review of Management and Business Research, 4(2), 391.

22. Rangkuti, Freddy. (2003). Measuring Customer Satisfaction: Measuring Techniques and Strategies Improving Customer Satisfaction. PT. Gramedia Pustaka Utama Jakarta.

23. Republic of Indonesia. (2000) of Government Regulation No. 52 of 2000 on the operation of Telecommunications Article 15 paragraph (1)).

24. Republic of Indonesia. (2015) Regulation of the Minister of Communication and Information of the Republic of Indonesia Number 7 of 2015 on the Second Amendment to the Regulation of the Minister of Communication and Informatics Number: 01 / Per / M.Kominfo / 01/2010 About the Implementation of Telecommunication Network

25. Roger, Ellis. (1995). Quality Assurance for University Teaching. USA : Open University Press.

26. Romeo, Maxi. (2008). Analysis of Customer Satisfaction, Price and Service orientation toward service quality and Loyalty by Customer

27. Schiffman, L. G., \& Kanuk, L. L. (2010). Consumer Behaviour. Edisi 10. Prentice Hall Inc.

28. Sia, Florencia T. \& Subagio, Hartono. (2013)., Influence Analysis of Price, Service Quality, And Corporate Image to Customer Loyalty With Customer Satisfaction As Variable Intervening Consumer Ipo Korean Cafe and Restaurant Surabaya. Journal of Marketing Management Vol. 1, No. 1, (2013) 1-8

29. Sunyoto, Danang. (2012). Marketing Management Basics: Concepts, Strategies and Cases. Yogyakarta, CAPS (Center of Publising Service).

30. Supriyono, P. (2001). Quality of Service: Theory and Applications. Jakarta: Mandar Maju Publisher.

31. Tjiptono, Fandi \& Diana, Anastasia, (2001). Total Quality Management. Yogyakarta: Andi Offset.

32. Tjiptono, Fandy. (2000). Management Services. Yogyakarta: Andi Publisher.

33. Tjiptono, Fandy. (2008). Marketing strategy. Yogyakarta: Andi publisher.

34. Toro, J. S. (2012). Analysis of influence of service quality and price on fairness with customer satisfaction customer loyalty, corporate image and variable trust as mediation: Studies in Consumer PO. Rosalia Indah Surakarta. Managerial Focus (Journal of Management \& Entrepreneurship), 11 (2), 195-212.

35. Wendha, A.A.P., Rahyuda, Ketut. \& Suasana. (2013). Effect of Service Quality on Satisfaction and Garuda Indonesia Customers. Journal of Management, Business Strategy, and Entrepreneurship Vol. 7, No. 1,

36. Widjaja, Amin, (2008). Customer Relationship Mnagement: customer relationship management, concepts and cases. Jakarta: Harvarindo. 